\title{
Ortaokul Matematik Öğretmeni Adaylarının Cebirsel İfade ve Denklemlere Yönelik Kurdukları Problemlerin İncelenmesi ${ }^{1}$
}

\author{
Melihan Ünlü ve Gülfem Sarpkaya Aktaş ${ }^{3}$
}

Makale geçmişi

Makale geliș tarihi: 7 Kasım 2016

Yayına kabul tarihi: 16 Mart 2017

Çevrimiçi yayın tarihi: 4 Nisan 2017

Öz: Bu araştırmanın amacı, ortaokul matematik öğretmeni adaylarının cebirsel ifade ve denklemlere ilişkin kurdukları problemlerin incelenerek sınıflandırılmasıdır. Araştırmaya ait veri 2012- 2013 bahar döneminde bir devlet üniversitesinin ilköğretim matematik öğretmenliği programında öğrenim görmekte olan 96 öğretmen adayından toplanmıştır. Veri toplama aracı olarak araştırmacılar tarafindan geliştirilen ve beş açık uçlu maddeden oluşan Problem Kurma Testi kullanılmıştır. Öğretmen adaylarından verilen cebirsel ifade ve denklemlere uygun problem kurmaları istenmiştir. Kurulan problemler betimsel analiz yöntemine uygun olarak sınıflandırılmıştır. Yapılan analizler sonucunda, öğretmen adaylarının cebirsel ifade ve denklemlere yönelik genel olarak sözel ve çözülebilen problemler kurdukları, kurulan problemlerde genellikle günlük dili kullandıkları tespit edilmiştir.

Anahtar Kelimeler: Cebirsel ifade ve denklemler, problem kurma, öğretmen adayı

DOI: $10.16949 /$ turkbilmat.303966

\begin{abstract}
The purpose of this study is to examine pre-service elementary mathematics teachers' problems posed about algebraic expressions and equations. Data was collected from 96 pre-service elementary mathematics teachers in the spring semester of 2012- 2013 who were enrolled in a teacher education program at a public university. Problem Posing Test consists 5 open ended items which were developed by researchers was used as a data collection tool. Pre-service elementary mathematics teachers were asked to pose problems corresponding to the algebraic expressions and equations. Problems were examined and classified. Descriptive statistics were used to determine pre-service elementary mathematics teachers' problem types. Findings of the study indicated that in general problem types were classified as story and solvable problems, they used daily language for posing problems.
\end{abstract}

Keywords: Algebraic expressions and equations, problem posing, pre-service teacher

See Extended Abstract

\section{Giriş}

Evrensel bir dil olan matematik çeşitli alanlara ayrılmıştır. Bu alanlardan birisi olan cebir, sayı ve sembolleri kullanarak bunlar arasındaki ilişkileri denklemlere dönüştüren bir matematik dalıdır ve matematiksel kavramların öğrenilmesinde çok önemli bir role sahiptir (Baki, 2008; Kieran, 1992; Van Dooren, Verschaffel \& Onghena, 2002). National Council of Teachers of Mathematics'e (NCTM, 2000) göre cebir öğrenme alanı, öğrencilerin örüntüleri ilişkilendirerek mantıksal çıkarım (akıl yürütme) yapma, problem çözme gibi üst düzey becerileri kazanmalarını sağlar. Ayrıca bu öğrenme alanında öğrencilerin örüntüleri, fonksiyonları ve bağıntıları kavraması; cebirsel semboller kullanarak matematiksel durumları göstermesi; nicel ilişkileri anlama ve göstermede matematiksel modelleri kullanması ve değişiklikleri analiz etmesi beklenir. Öğrencilerin

\footnotetext{
${ }^{1}$ Bu çalıșma Roma'da düzenlenen 2013 INTE kongresinde sunulan sözlü bildirinin genişletilmiş halidir.

${ }^{2}$ Yrd. Doç. Dr., Aksaray Üniversitesi, Eğitim Fakültesi, İlköğretim Matematik Eğitimi, Türkiye, melihanunlu@yahoo.com

${ }^{3}$ Yrd. Doç. Dr., Aksaray Üniversitesi, Eğitim Fakültesi, İlköğretim Matematik Eğitimi, Türkiye, gulfemsarpkaya@yahoo.com
} 
cebir alanında başarılı olabilmeleri için özellikle eşitlik ve değişkenleri içeren sembollerle gösterimlerin kavramsal olarak anlaşılması önem taşımaktadır (Van de Walle, Karp \& Bay-Williams, 2012). Cebir öğrenme alanı ile ilgili araştırmalar incelendiğinde öğrencilerin cebirsel ifade ve denklemler konularını anlamada (Cortes \& Pfaff, 2000; Lee, 2002; Stafylidou \& Vosniadou, 2004; Şandır, Ubuz ve Argün, 2003; Tsamir \& Bazzini, 2004; Vlassis, 2004), cebirsel ifade ve ilişkilere anlam vermede, özdeşlik formüllerini oluşturma, dönüştürme ve yorumlamada (Graham \& Thomas, 2000; Stacey \& MacGregor, 1997; Steinberg, Sleeman \& Ktorza, 1990) güçlükler yaşadıkları belirlenmiştir. Ayrıca öğrencilerin kavramlar arasındaki ilişkileri kavrayamadıkları için cebir konusundaki bilgilerini problem çözümlerinde kullanamadıkları da tespit edilmiştir (Brown ve ark., 1988). Halbuki matematik eğitiminin temel amaçlarından biri de öğrencilerin problem çözme becerilerini geliştirmektir (Milli Eğitim Bakanlığ1 [MEB], 2013).

Problem bireyde karmaşa oluşturan ve çözümü belli olmayan bir soru ya da durum olarak tanımlanabilir (Sheffield \& Cruikshank, 2005). Matematiksel problemler sözel problemler ve sürece dayalı problemler olarak sınıflandırılmıştır. Sözel problemler bir ya da daha fazla işlemle hemen çözülebilecek problemler iken sürece dayalı problemler daha karmaşık düşünme ve organizasyon becerisi gerektirir (Souviney, 1994'den akt., Kilıç, 2013). Problem çözme ise çözümün bilinmediği durumlarda çözüme ulaşmak için izlenen yol olarak tanımlanabilir (Polya, 1962). Ortaokul Matematik Öğretim Programı'nda problem çözmenin zaman zaman bir öğretim yaklaşımı veya bir öğrenme vasıtası olarak da ele alındığı görülmektedir (MEB, 2013).

Problem çözmenin birçok bileşeni vardır ve en önemlilerinden biri problem kurmadır. Öğrencilerin matematiksel kavramları ve işlemleri anlayıp anlamamalarına ilişkin geniş bir bilgi sunan problem kurmanın (Stoyanova, 2003) matematiksel araştırmaların ve matematik öğretiminin temelinde yer alması gerekmektedir (Brown \& Walter, 2005). NCTM (2000) Okul Matematiği için İlkeler ve Standartlar'da, öğrencilere matematik içindeki ve dışındaki durumları kullanarak problemler oluşturabilecekleri firsatlar sunulması gerektiği üzerinde durulmuştur. Problem kurma, var olan ya da yeniden düzenlenerek verilen problem hakkında yeni problemler üretmek olarak tanımlanabilir (Cai \& Hwang, 2002; English, 2003; Ticha \& Hospesova, 2009). Silver (1994) problem kurma sürecinin sunulan matematiksel bir ifadeden özgün problemler üretilmesi, çözümü yapılmış bir problemin yeniden düzenlenmesi (formüle edilmesi) veya oluşturulması, mevcut bir problemden yola çıkarak problemin şartlarının değiştirilerek yeni problemler kurulması şeklinde üç farklı bilişsel etkinlikten oluştuğunu belirtmiştir. Stoyanova ve Ellerton (1996) problem kurma durumlarını serbest problem kurma, yarı-yapılandırılmış problem kurma ve yapılandırılmış problem kurma biçiminde ele almışlardır. Yapılandırılmış problem kurmada, öğrencilerden verilen yapılandırılmış problem veya problem durumlarına uygun problemler oluşturmaları istenirken, yarı-yapılandırılmış problem kurmada açık-uçlu durumlar ya da tamamlanmamış problemlere uygun problemler kurmaları istenir. Görsel ve sözel açık uçlu temsillere yönelik problem kurma 
etkinlikleri de yarı-yapılandırılmış problem kurmada yer alır. Serbest problem kurmada ise herhangi bir sınırlandırma olmaksızın verilen duruma uygun problemler kurulması söz konusudur.

Problem kurmanın bir matematiksel etkinlik olarak öğrenciler ve öğretmenler açısından pek çok faydası vardır. Problem kurma durumları öğrencilerin matematiği anlamlandırmalarına yardımcı olur (Stoyanova, 2003), öğretmen ve öğrencilere matematiksel yaratıcılıklarını geliştirmek için firsatlar sunar (Sheffield \& Cruikshank, 2005; Van Harpen \& Sriraman, 2013), öğrencilerin yaptıkları hataların ve matematiksel kavram yanılgılarının nedenlerini keşfetmelerini sağlar (Ticha \& Hospesova, 2009) ve öğretmen adaylarının eğitiminde öğretim stratejisi olarak kullanılabilir (Toluk-Uçar, 2009).

Alanyazındaki çalışmalar incelendiğinde matematik alanında öğretmenlerin ve öğretmen adaylarının kesirler (Işık, 2011; Kılıç, 2013; Toluk-Uçar, 2009; Ünlü ve Ertekin, 2012), geometri (Lavy \& Bershadsky, 2003; Van Harpen \& Sriraman; 2013), olasıllk (Silber \& Cai, 2017; Yıldız ve Baltac1, 2015), mutlak değer (Güveli, 2015), oran-orantı (Şengül \& Katranc1, 2015) ve kümeler (Şengül \& Katranc1, 2012) konusunda problem kurma becerilerinin araştırıldığı belirlenmiştir. Araştırmalar sonucunda öğretmen adaylarının özellikle kesirler konusunda problem kurmakta zorlandıkları görülmüştür. Işık, Işık ve Kar (2011) ise matematik öğretmeni adaylarının sözel ve görsel temsillere yönelik kurdukları problemleri analiz etmişler ve öğretmen adaylarının farklı temsillere yönelik problem kurma başarılarının genel olarak düşük olduğunu belirtmişlerdir. Ayrıca Aydoğdu- İskenderoğlu ve Güneş (2016) pedagojik formasyon eğitimi alan matematik bölümü öğrencilerinin problem kurma becerilerini incelemişlerdir. Araştırmanın sonucunda; öğrencilerin çoğunun verilen sayı ve işlemlerin yanı sıra matematiksel eşitlikleri kullanarak problem kurma durumlarında daha başarılı olduklarını bulmuşlardır. Esas bileşeninin eksik olduğu, matematiksel olarak veri ve bilgi içeren durumlar ile verilen açık uçlu problem ifadesini değiştirerek problem kurma durumlarında matematiksel eşitlikleri kullanma durumlarına göre daha az başarılı olduklarını ortaya koymuşlardır.

Bunun yanında cebirsel ifadeler ve denklemler ile ilgili yapılan çalışmalar da mevcuttur (Akkan, Çakıroğlu ve Güven, 2009; Işık \& Kar, 2012a). Işık ve Kar (2012a) öğretmen adaylarının matematiksel sembolle ifade edilen birinci dereceden bir bilinmeyenli ve iki bilinmeyenli denklemlere ilişkin kurmuş oldukları problemleri incelemişlerdir. Araştırmalarının sonucunda, öğretmen adaylarının problem kurarken matematiksel notasyonların (işlemler ve parantezler) yanlış çevrilmesi, bilinmeyenlere gerçekçi olmayan değerlerin verilmesi, denklem yapılarının değiştirilerek problem kurulması gibi hatalar yaptıklarını belirlemişlerdir. Hâlbuki cebirsel sözel problemler aritmetikten cebire geçişi sağlayan temel kavramlardır ve matematik eğitiminde oldukça önemlidir (Dede, 2004). Ayrıca öğrencilerin kavramlar arasındaki karşılıklı geçişleri ve ilişkileri görebilmeleri için, ders sürecinde günlük yaşam problemlerinin kullanılması tavsiye edilmektedir (Baki, 2008). Bu bağlamda problemlerin cebir öğrenme sürecinde önemli bir yeri olduğu söylenebilir. 
Öğretmen ve öğretmen adaylarının cebirsel ifadeler ve denklemler konusunda kavramsal olarak edindikleri bilgiler, öğrencilerinin etkin bir şekilde cebiri öğrenmelerine yardımcı olabilecektir. Bu nedenle matematik derslerinde cebirsel ifade ve denklemlerin kavramsal olarak anlaşılmasını sağlayacak problem kurma çalışmalarına yer verilmesi önemlidir. Problem kurma, cebirsel ifade ve denklemler öğrencilerin birçok alanda ve sınıf düzeyinde karşılaşmış oldukları kavramlar olmasına rağmen bu konuların önemi ve bu konulardaki yaşanan zorluklar, konu ile ilgili araştırma yapılmasını gerekli kılmaktadır. Diğer yandan öğretmenlerin öğrencilerine problem kurma çalışmaları yaptırabilmeleri bu alanda bilgi ve tecrübe sahibi olmalarına bağlıdır. Bu bakış açısı ile öğretmenlerin hem iyi problem kuran hem de öğrencilerine problem kurma çalışmaları yaptıracak donanımda olmaları önem taşımaktadır (Yenilmez ve Ev-Çimen, 2014). Bu bağlamda gelecekte sinıflarda bu konunun ortaokul düzeyinde öğrencilere kazandırılmasında birinci derecede sorumlu olacak olan ortaokul matematik öğretmeni adaylarının cebirsel ifade ve denklemlere ilişkin problemleri kurup kuramadıklarının ve hangi tür problemler kurabildiklerinin açığa çıkarılmasının matematik eğitimi açısından önem taşıdığı düşünülmektedir. Ayrıca araştırmada cebirsel ifade ve denklemlere yönelik sembolik ifadelerin yanında, görsel ve sözel temsillere yönelik kurulan problemlerin sınıflandırılmasının alanyazına katkı sağlayacağı düşünülmektedir. Bu sebeple çalışmada, ortaokul matematik öğretmen adaylarının cebirsel ifade ve denklemlere ilişkin kurdukları problemlerin incelenerek sınıflandırılması amaçlanmıştır.

\section{Yöntem}

\subsection{Araştırma Deseni}

$\mathrm{Bu}$ araştırma betimsel tarama modelindedir. Tarama araştırmaları "bir konuya ya da olaya ilişkin katılımcıların görüşlerinin, ilgi, beceri, yetenek, tutum gibi özelliklerinin belirlendiği araştırmalardır" (Büyüköztürk, Çakmak- Kılıç, Akgün, Karadeniz ve Demirel, 2011). Bu araştırmada ortaokul matematik öğretmeni adaylarının cebirsel ifade ve denklemlere ilişkin kurdukları problemlerin sınıflandırılması amaçlandığından betimsel tarama modeli tercih edilmiştir.

\section{2. Çalışma Grubu}

$\mathrm{Bu}$ araştırma 2012-2013 bahar döneminde bir devlet üniversitesinin eğitim fakültesi ilköğretim matematik öğretmenliği programında öğrenim görmekte olan 96 öğretmen adayı ile yürütülmüştür. Araştırmaya katılan öğretmen adaylarının belirlenmesinde seçkisiz olmayan örnekleme yöntemlerinden amaçsal örnekleme yöntemi kullanılmıştır. Amaçsal örnekleme çalışmanın amacına bağlı olarak, durumların gözden geçirilip zengin bilgi verecek grubun üzerinde araştırma yapılmasını olanaklı kılar (Büyüköztürk ve ark.,

2011). Amaçsal örnekleme yönteminde ise maksimum çeşitlilik yaklaşımı benimsenmiştir. Problemin geniş bir çerçeveden betimlenmesi, farklı durumlar arasında ortak ve ayrılan yönlerin ortaya çıkarılması bu örnekleme yaklaşımında ön plandadır (Büyüköztürk ve ark., 2011). Öğretmen adaylarının 2, 3 ve 4. sınıftan seçilme nedeni, 
problem kurma ile ilgili bir araştırma yapıldığından matematik öğretimi ile ilgili dersi almış olanların bakış açısını görebilmektir. Öğretmen adaylarından bir kısmı ikinci sınıfta seçmeli ders olarak "Problem Çözme Stratejileri”, üçüncü ve dördüncü sınıf öğrencileri ise üçüncü sınıfta "Özel Öğretim Yöntemleri I-II" derslerini almışlardır. Bu öğretmen adaylarının 37'si 2.sınıf, 30'u 3.sınıf ve 29'u 4. sınıfta öğrenim görmektedir. Cinsiyet açısından çalışma grubu incelendiğinde öğretmen adaylarının 76'sı bayan, 20'si erkektir. Öğretmen adaylarının yaşları 19 ile 23 aralığındadır.

\subsection{Veri Toplama Aracı}

Veri toplama aracı olarak alanyazın taraması sonucunda araştırmacılar tarafindan geliştirilen Problem Kurma Testi (PKT) kullanılmıştır. Ortaokul Matematik 5-8 Öğretim Programı (2013) ve ders kitapları incelenerek oluşturulan bu test, cebirsel ifade ve denklemlere yönelik beş açık uçlu sorudan oluşmaktadır. Testte Stoyanova ve Ellerton'ın (1996) serbest ve yarı-yapılandırılmış problem kurma durumlarına yer verilmiştir. Yarıyapılandırılmış problem kurma durumlarında sembolik ifade, sözel ve görsel temsiller kullanılmıştır. PKT'de yer alan 2, 3, 4 ve 5. problemler yarı-yapılandırılmış problem kurma şeklinde tasarlanmıştır. PKT'de yer alan sorular şöyledir:

1. soru "Günlük yaşantınızda karşılaştığınız olaylardan yararlanarak birinci dereceden iki bilinmeyenli denklem kullanılarak çözülebilecek bir problem kurunuz" şeklindedir. $\mathrm{Bu}$ serbest problem kurma şeklinde tasarlanmış bir soru olup, öğretmen adaylarından birinci dereceden iki bilinmeyenli denklemi günlük hayatla ilişkilendirmesi beklenmektedir. Ortaokul Matematik Öğretim Programı’nda belirtildiği gibi denklemlerin günlük hayatla ilişkilendirilmesi ve sözel olarak ifade edilmesi açısından bu maddeye yer verilmiştir.

2. soru "Verilen $x+\frac{x}{2}+(6000-2 x)=5000$ cebirsel denklemine uygun bir problem kurunuz" şeklindedir. Bu soruda sembolik olarak verilen birinci dereceden bir bilinmeyenli cebirsel denklemine uygun bir problem kurmaları istenmiştir.

3. soru "Bir tavuk çiftliğindeki tavukların sayısı her ay bir öncekinin 3 katına çıkmaktadır.......... ifadesini tamamlayacak şekilde bir problem kurunuz" şeklindedir. Burada öğretmen adaylarına açık uçlu bir durum verilmiş olup öğretmen adaylarından sözel temsillere yönelik problem kurmaları beklenmektedir.
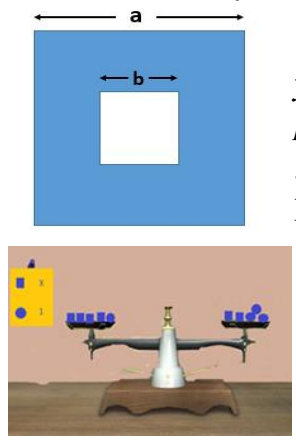

4. soru "Kenar uzunlukları a ve b olan kare şekildeki gibi iç içe yerleştiriliyor. Bu modelde ifade edilen cebirsel ifadeye uygun bir problem kurunuz." şeklindedir. Burada öğretmen adaylarının geometriyi cebirle ilişkilendirmeleri ve görsel temsillere yönelik problem kurmaları beklenmektedir.

5. soru "Şekilde verilen eşit kollu terazi modelindeki cebirsel denkleme uygun olacak bir problem kurunuz" şeklindedir. Bu soruyla öğretmen adaylarının görsel temsile yönelik problem kurup kuramadıkları belirlenmeye çalışılmıştır. 
Veri toplama aracının kapsam geçerliliğinin sağlanması için uzman görüşüne başvurulmuştur. Ayrıca 5 öğretmen adayıyla ön uygulama yapılmıştır. Soruların anlaşılabilirliği ve matematiksel olarak uygunluğu konusundaki görüşler doğrultusunda düzeltmeler yapılarak PKT'ye son şekli verilmiştir.

\subsection{Verilerin Toplanması}

Öğretmen adaylarından PKT'de verilen cebirsel denklemlere veya şekillere uygun problem kurup yazmaları istenmiştir. Bu süreçte öğretmen adaylarına süre kısıtlaması yapılmamıştır ve katılımcıların birbirlerinden etkilenmemeleri için gerekli önlemler alınmıştır.

\subsection{Verilerin Analizi}

Araştırmada toplanan veriler öğretmen adaylarının problem kurma testindeki sembolik, görsel ve sözel ifadelere uygun olarak kurdukları problemlerden oluşmaktadır. Öğretmen adaylarının kurmuş oldukları problemler, araştırmacılar tarafindan ayrıntılı olarak incelenmiş ve betimsel analize uygun olarak analiz edilmiştir. Problem çeşitleri kodlanarak sınıflandırılmıştır. Problemlerin analizinde Kılıç (2013) ve Dede (2004) tarafindan yapılan sınıflandırmalardan yararlanarak araştırmacılar tarafından oluşturulan sınıflandırma kullanılmıştır. Sınıflandırmaların frekans ve yüzdeleri hesaplanmış ve tablo şeklinde ifade edilmiştir. Kurulan problemlerin sınıflandırılmasında araştırmacılar bağımsız olarak çalışmışlar sonrasında oluşturulan sınıflandırmalar karşılaştırılmıştır. Sınıflandırmada farklılık olan problem çeşitleri tartışılarak görüş birliğine varılmıştır. Miles ve Huberman'ın (1994) [Güvenirlik = Görüş Birliği/(Görüş Birliği + Görüş Ayrılığı)] güvenilirlik katsayısı kullanılarak sınıflandırmada araştırmacılar arası tutarlık \%94 olarak hesaplanmıştır. Güvenirlik hesapları \%70'in üzerinde olduğundan sınıflandırmanın güvenilir olduğu söylenebilir (Miles \& Huberman, 1994). Problemlerin sınıflandırılması Şekil 1'de gösterilmiştir:

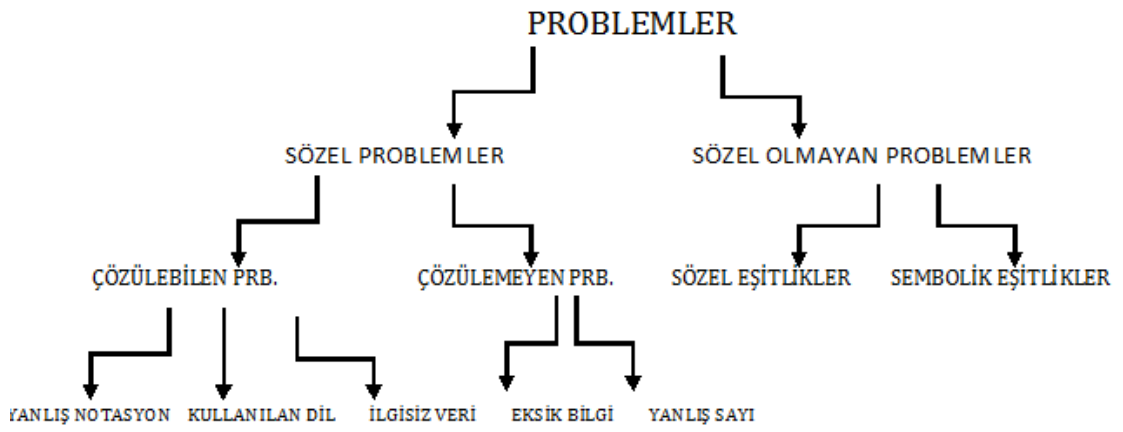

Şekil 1. Problemlerin sınıflandırılması 
Şekil 1'de görüldüğü gibi PKT'de öğretmen adaylarının problem özelliği taşımayan veya boş bıraktıkları cevapları problem teşkil etmeyenler olarak sınıflandırılmıştır. Problem bireyde karmaşa oluşturan ve çözümü belli olmayan bir soru ya da durum (Sheffield \& Cruikshank, 2005) olduğundan ortaokul matematik öğretmeni adaylarının yazdıkları, ortaokul öğrencileri için merak uyandırabilecek ya da ilk bakışta çözümü olmayacak soru veya durumlar problem olarak kabul edilmiştir. Öğretmen adaylarının kurdukları problem türleri sözel ve sözel olmayan problemler olarak alt sinıflara ayrılmışıır.

Sözel problemler kendi içerisinde çözülebilen ve çözülemeyen problemler şeklinde sınıflandırılmaktadır. Bunlardan çözülebilen problemler kullanılan dil, ilgisiz veri ve yanlış notasyon; çözülemeyen problemler ise eksik bilgi ve yanlış sayı kullanımı olarak alt sınıflara ayrılmıştır. Kılıç (2013) sınıflandırmasında çözülemeyen problemlerin görünüşte mantıklı bir yapıya sahip olmasına rağmen problemin çözümü yapıldığında gerçekçi olmayan sonuçlar verdiğini ifade etmiştir. Bu durumun sebebini ise problemin eksik bilgi içermesi veya yanlış sayılar kullanılarak kurulması olarak açıklamıştır. Kullanılan dil sınıflaması ise kendi içerisinde günlük dil, günlük-sembolik dil ve sembolik dil şeklinde alt sınıflara ayrılmıştır (Dede, 2004). Sözel olmayan problemler ise sözel eşitlikler ve sembolik eşitlikler olarak sınıflandırılmıştır.

Bir problem günlük hayatla ilişkilendirilerek yani hikayeleştirilerek kurulmuşsa bu problem sözel problem olarak değerlendirilmiştir. Örneğin; "Manavdan aldiğ 2 kg elma ve $3 \mathrm{~kg}$ portakala $12 \mathrm{TL}$ ödeyen adam, eğer $1 \mathrm{~kg}$ elma ve $2 \mathrm{~kg}$ portakal alsaydl $7 \mathrm{TL}$ ödeyecekti. Buna göre $1 \mathrm{~kg}$ elma kaç TL'dir?" problemi sözel problem olarak sinıflandırılmıştır. Problemin yapısına ve çözümüne bakıldığında problemde kullanılan sayıların ve elde edilen sonucun mantıklı ve gerçekçi olduğu için çözülebilen problem; kullanılan dil açısından ise günlük hayatla ilişkilendirildiği için günlük dil olarak sınıflandırılmıştır. "Kırtasiyeden 1 kalem ve 3 defter aldığımda 10 TL, 2 kalem ve 5 defter aldığımda ise 20 TL ödedim. Buna göre bir defterin fiyatı kaç TL'dir?” problemi sözel olarak yazılmış ve görünüşte mantıklı bir problemdir fakat sonuçta defterin fiyatının $0 \mathrm{TL}$ çıkması gerçek hayatta mümkün bir durum değildir. Bundan dolayı problemin yanlış sayılar kullanılarak kurulduğu düşünülüp yanlış sayı olarak sınıflandırılmıştır. "Dört katının bir fazlası iki katının ü̧̈ fazlasına eşit olan sayı kaçtır?” şeklinde kurulan problem ise hikayeleştirilmediği için sözel olmayan problem olarak değerlendirilmiştir. Denklemin sözel olarak ifade edilmesiyle oluşturulduğundan sözel eşitlikler olarak sınıflandırılmıştır. Bunun yanında " $4 x+1=2 x+3$ ise $x=$ ?" şeklindeki ifadeler ise hikayeleştirilmeden doğrudan matematik semboller şeklinde ifade edildiğinden sözel olmayan problemlersembolik eşitlikler olarak sınıflandırılmıştır.

\section{Bulgular}

PKT' de yer alan maddelere ilişkin öğretmen adaylarının kurdukları problemlere ilişkin bulgular aşağıda verilmiştir: 


\subsection{PKT'nin 1.maddesine ilişkin bulgular}

İlk soru "Günlük yaşantınızda karşılaştı̆̆ınız olaylardan yararlanarak birinci dereceden iki bilinmeyenli denklem kullanılarak çözülebilecek bir problem kurunuz" şeklindedir. $\mathrm{Bu}$ maddede öğretmen adaylarından denklem kullanarak çözülebilecek serbest bir problem kurmaları istenmiştir. Öğretmen adaylarının kurdukları problemler incelendiğinde 1. madde için sözel olmayan problemlere rastlanmadığından problemler, sözel problemler ve problem teşkil etmeyenler şeklinde sınıflandırılmış ve sınıflamalar için frekans ve yüzdeler Tablo 1' de verilmiştir:

Tablo 1. Ortaokul matematik öğretmeni adaylarının 1. madde için kurdukları problem çeşitleri

\begin{tabular}{|c|c|c|c|c|c|c|c|c|c|c|c|c|c|c|c|c|}
\hline \multirow[b]{4}{*}{ Sinıf } & \multicolumn{14}{|c|}{ Sözel Problemler } & \multirow{4}{*}{\multicolumn{2}{|c|}{$\begin{array}{c}\text { Problem } \\
\text { Teşkil } \\
\text { Etmeyenler }\end{array}$}} \\
\hline & \multicolumn{10}{|c|}{ Çözülebilen Problemler } & \multicolumn{4}{|c|}{$\begin{array}{c}\text { Çözülemeyen } \\
\text { Problemler }\end{array}$} & & \\
\hline & \multicolumn{6}{|c|}{ Kullanılan Dil } & \multirow{2}{*}{\multicolumn{2}{|c|}{$\begin{array}{c}\text { Yanlış } \\
\text { Notasyon }\end{array}$}} & \multirow{2}{*}{\multicolumn{2}{|c|}{$\begin{array}{l}\text { İlgisiz } \\
\text { Veri }\end{array}$}} & \multirow{2}{*}{\multicolumn{2}{|c|}{$\begin{array}{c}\text { Eksik } \\
\text { bilgi }\end{array}$}} & \multirow{2}{*}{\multicolumn{2}{|c|}{$\begin{array}{c}\text { Yanlış } \\
\text { sayı }\end{array}$}} & & \\
\hline & & & & ük Dil & & $\begin{array}{l}\text { lik v } \\
\text { l Dil }\end{array}$ & & & & & & & & & & \\
\hline & f & $\%$ & f & $\%$ & f & $\%$ & f & $\%$ & $f$ & $\%$ & $f$ & $\%$ & $\mathbf{f}$ & $\%$ & f & $\%$ \\
\hline 2 & - & - & 13 & 14.1 & 2 & 2.1 & 3 & 3.2 & 1 & 1 & 7 & 7.4 & 8 & 8.3 & 3 & 3.1 \\
\hline 3 & - & - & 19 & 19.6 & 1 & 1 & 1 & 1 & 1 & 1 & 1 & 1 & 6 & 6.3 & 1 & 1 \\
\hline 4 & - & - & 19 & 19.6 & - & - & 2 & 2.1 & 1 & 1 & 1 & 1 & 6 & 6.3 & - & - \\
\hline Toplam & - & - & 51 & 53.2 & 3 & 3.1 & 6 & 6.3 & 3 & 3.1 & 9 & 9.4 & 20 & 20.8 & 4 & 4.1 \\
\hline
\end{tabular}

Ortaokul matematik öğretmeni adaylarının kurdukları, birinci dereceden iki bilinmeyenli denklem kullanılarak çözülebilen problemlere ilişkin Tablo 1'deki veriler incelendiğinde, öğretmen adaylarından 92'sinin (\%96.9'unun) sözel matematik problemi kurduğu belirlenmiştir. Kurulan sözel problemlerden \%65.7'si çözülebilen problemlerdir. Çözülebilen problemlerin \%3.1 'i ilgisiz veri, \% 6.3'ü yanlış notasyon olarak sinıflandırılırken, \%53.2'si günlük dil ve \% 3.1'i günlük ve sembolik dil olarak sınıflandırılmıştır. Öğretmen adaylarının kurdukları sözel-çözülebilen-günlük dil sınıflamasına giren problem örneği Şekil 2'de verilmiştir:

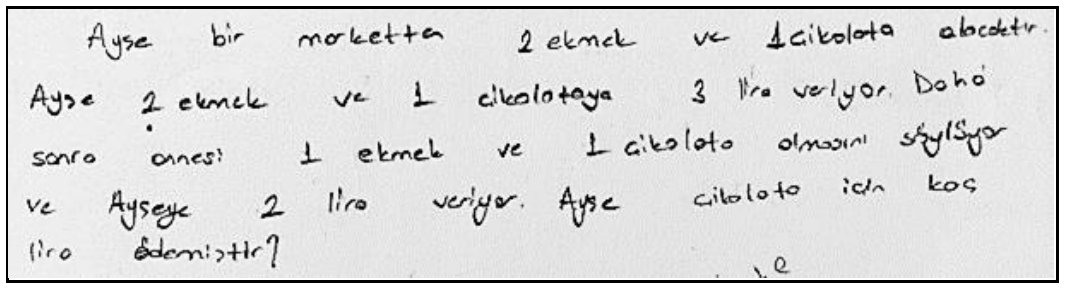

Şekil 2. Sözel-çözülebilen-günlük dil sınıflamasına giren problem örneği

Şekil 2'deki problem hikayeleştirildiği, sözel olarak yazıldığı için sözel problem, sonuçları mantıklı ve gerçeğe uygun olduğundan çözülebilen problem ve günlük hayattaki dil kullanıldığg için kullanılan dil açısından da günlük dil olarak sınıflandırılmıştır. 
Sözel matematik problemi kuran öğretmen adaylarından çözülemeyen sözel problem kuranların oranı \%30.2'dir. Bu problemlerden \%20.8'i yanlış sayı, \%9.4'ü eksik bilgi sınıflamalarında yer almaktadır. Öğretmen adaylarının sözel-çözülemeyen problem-eksik bilgi sınıflamasına giren problem örneği Şekil 3'te verilmiştir:

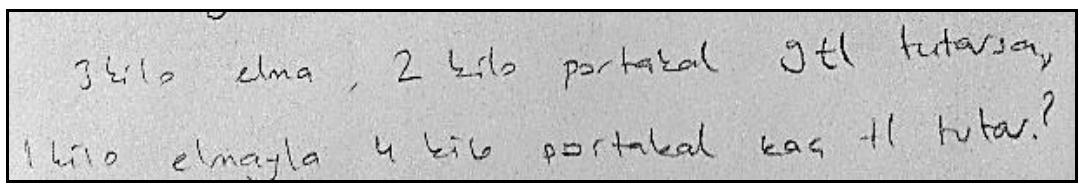

Şekil 3. Sözel-çözülemeyen problem-eksik bilgi sınıflamasına giren problem örneği

Şekil 3'teki problemin çözümünün yapılabilmesi için yeteri kadar verinin bulunmadığı görülmektedir. $\mathrm{Bu}$ nedenle problem çözülemeyen problem-eksik veri sınıflandırması içerisine dâhil edilmiştir. Problemde birinci dereceden iki bilinmeyenli denklemin bir tanesi kurulabilmektedir $(3 x+2 y=9)$ fakat problemde ikinci denklemi kurmak için yeterli bilgi bulunmamaktadır.

Öğretmen adaylarından 4 tanesinin (\%4.1'inin) ise birinci dereceden iki bilinmeyenli denkleme uygun bir problem kuramadığ belirlenmiştir ve bu durumu ifade eden örnek Şekil 4'te gösterilmiştir:

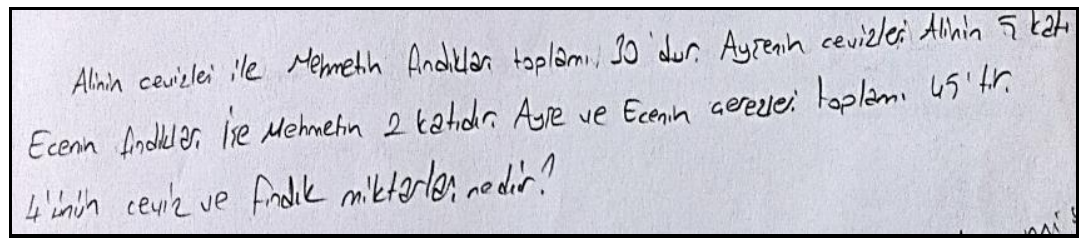

Şekil 4. Problem teşkil etmeyenler sınıflamasına örnek

Şekil 4'teki ifade incelendiğinde, ifadede birden fazla değişken olduğu ve ifadeler mantıklı değerler içermediği için problem teşkil etmeyenler sınıfında değerlendirilmiştir.

Genel olarak öğretmen adaylarının kurdukları birinci dereceden iki bilinmeyenli denklem kullanılarak çözülebilecek günlük hayat problemleri incelendiğinde, çok büyük bir bölümünün sözel matematik problemi kurabildiği belirlenmiştir. Kurulan problemler en fazla günlük dil kullanılarak oluşturulmuştur. Bu bulgu öğretmen adaylarının birinci dereceden iki bilinmeyenli denklemleri günlük hayatla ilişkilendirebildiklerinin bir göstergesi olarak kabul edilebilir. Sözel matematik problemi kuran öğretmen adaylarından çözülemeyen sözel problem kuranların oranı da oldukça fazladır. Kurulan problemlerin çözülememe nedenleri incelendiğinde en sık rastlanan durum yanlış sayılar kullanılarak problem kurulması, diğer bir durum ise problemin eksik bilgi içermesidir. Bu durum öğretmen adaylarının kurdukları problemlerin çözülebilir olup olmadığına dikkat etmediklerini göstermektedir. 


\subsection{PKT'nin 2.maddesine ilişkin bulgular}

PKT'de yer alan 2. maddede öğretmen adaylarından birinci dereceden bir bilinmeyen içeren cebirsel denkleme yönelik problem kurmaları istenmiştir. İkinci soru "Verilen

$$
x+\frac{x}{2}+(6000-2 x)=5000 \text { cebirsel denklemine uygun bir problem kurunuz" }
$$

şeklindedir. Öğretmen adaylarının kurmuş oldukları problemler, sözel problemler, sözel olmayan problemler ve problem teşkil etmeyenler şeklinde sınıflandırılarak bu problem çeşitlerinin frekans ve yüzdeleri Tablo 2' de özetlenmiştir:

Tablo 2. Ortaokul matematik öğretmeni adaylarının verilen cebirsel denklem için kurdukları problem çeşitleri

\begin{tabular}{|c|c|c|c|c|c|c|c|c|c|c|c|c|c|c|c|c|}
\hline \multirow{4}{*}{ Sinıf } & \multicolumn{12}{|c|}{ Sözel Problemler } & \multicolumn{2}{|c|}{$\begin{array}{l}\text { Sözel Olmayan } \\
\text { Problemler }\end{array}$} & \multirow{3}{*}{\multicolumn{2}{|c|}{$\begin{array}{l}\text { Problem } \\
\text { Teşkil } \\
\text { Etmeyenler }\end{array}$}} \\
\hline & & & & & özüi & en $\mathbf{P}$ & plen & & & & & $\begin{array}{l}\text { emeyen } \\
\text { mler }\end{array}$ & \multirow{2}{*}{\multicolumn{2}{|c|}{ Sözel eşitlikler }} & & \\
\hline & \multicolumn{2}{|c|}{$\begin{array}{l}\text { Sembolik } \\
\text { Dil }\end{array}$} & \multicolumn{2}{|c|}{$\begin{array}{l}\text { Günlük } \\
\text { Dil }\end{array}$} & \multicolumn{2}{|c|}{$\begin{array}{l}\text { Sembolik } \\
\text { ve Günlük } \\
\text { Dil }\end{array}$} & \multicolumn{2}{|c|}{$\begin{array}{l}\text { Yanlış } \\
\text { Notasyon }\end{array}$} & \multicolumn{2}{|c|}{$\begin{array}{l}\text { İlgisiz } \\
\text { Veri }\end{array}$} & \multicolumn{2}{|c|}{ Eksik bilgi } & & & & \\
\hline & f & $\%$ & f & $\%$ & $\mathbf{f}$ & $\%$ & f & $\%$ & f & $\%$ & f & $\%$ & f & $\%$ & f & $\%$ \\
\hline 2 & - & - & 9 & 9.4 & 8 & 8.2 & 5 & 5.2 & 8 & 8.3 & - & - & 6 & 6.3 & 1 & 1 \\
\hline 3 & 1 & 1 & 13 & 14.1 & 4 & 4.2 & 1 & 1 & 7 & 7.3 & 1 & 1 & 2 & 2.1 & 1 & 1 \\
\hline 4 & - & - & 15 & 15 & 3 & 3.2 & 3 & 3.2 & - & - & - & - & 4 & 4.2 & 4 & 4.2 \\
\hline Toplam & 1 & 1 & 37 & 38.6 & 15 & 15.6 & 9 & 9.4 & 15 & 15.7 & 1 & 1 & 12 & 12.5 & 6 & 6.2 \\
\hline
\end{tabular}

Tablo 2'ye göre öğretmen adaylarının yazdıkları ifadelerden toplamda \%93.8'i problem sınıfinda değerlendirilmiştir. \%81.3'ü sözel matematik problemi, \%6.2'si ise problem teşkil etmeyenler olarak sınıflandırılmıştır. Sözel problemlerden \%79.3'ü çözülebilen problemlerdir. Çözülebilen problemlerden ise \%15.7'si ilgisiz veri, \%9.4'ü yanlış notasyon, \%38.6's1 günlük dil ve \% 15.6's1 günlük ve sembolik dil olarak sınıflandırılmıştır. Öğretmen adaylarının kurdukları sözel problem çeşitleri için örnekler ise aşağıda verilmiştir:

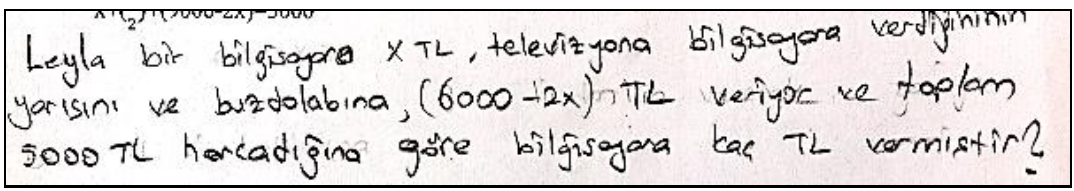

Şekil 5. Sözel-çözülebilen problem-günlük ve sembolik dil sınıflamasına örnek

Yukarıda verilen problem çözülebilen sözel probleme örnek olarak gösterilebilir. Burada öğretmen adayı hem günlük hayattaki alışverişi örnek vermiş, hem de bilinmeyen $\mathrm{x}$ değerine yer vermiştir. Bundan dolayı kullanılan dil açısından günlük ve sembolik dil kategorisinde sınıflandırılmıştır. 


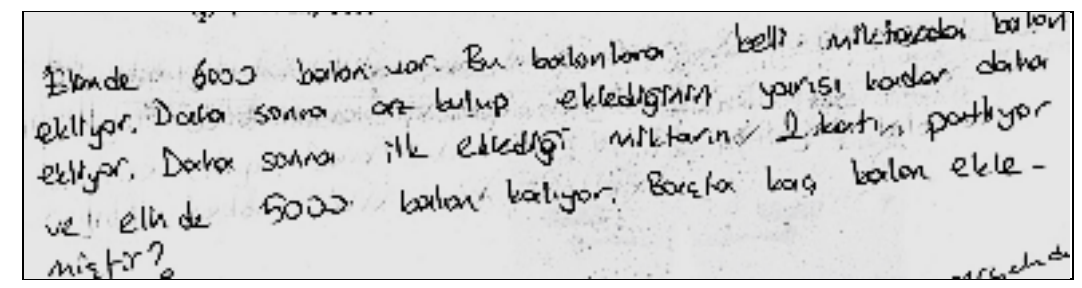

Şekil 6. Sözel-çözülebilen problem-yanlış notasyon sınıflamasına örnek

Şekil 6'da verilen problem çözülebilen sözel bir problemdir. Kurulan problemin çözümü için denklem yazıldığında $6000+x+\frac{x}{2}-2 x=5000$ şeklindedir. Problemin soruda verilen cebirsel denklemdeki parantezi tam olarak karşılamadığı belirlendiğinden yanlış notasyon olarak sınıflandırılmıştır.

Sözel matematik problemlerinden çözülemeyen problemlerin oranı \%1'dir. $\mathrm{Bu}$ problem ise eksik bilgi bulunduğundan çözülemeyen problemdir.

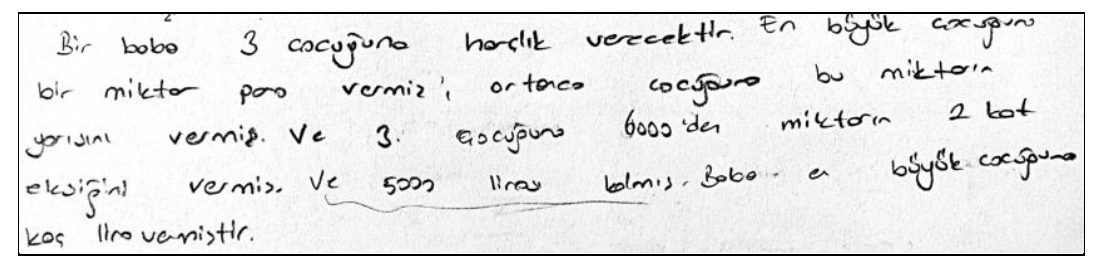

Şekil 7. Sözel problem-çözülemeyen problem-eksik veri sınıflamasına örnek

Şekil 7'de verilen problem, çözülemeyen sözel bir problemdir. Problemin çözülememesinin nedeni eksik veri içermesidir. Problemin verilen cebirsel denkleme uygun olarak çözülebilmesi için "elinde 5000 lirası kalmış" yerine "üç çocuğa toplam 5000 lira harçlık vermiş" şeklinde ifade edilmesi gerekirdi.

Kurulan problemlerden $\% 12.5$ 'i sözel olmayan matematik problemi olarak sınıflandırılmıştır. Bu sınıflamaya örnek Şekil 8'de verilmiştir:

Bir soy, bu sayinin yorsi ve 6000'den bu soyinin 2 katinin Gikotilmasyla elde edilar sginin toplani 5050'dir. Bu sas koctir?

Şekil 8. Sözel olmayan problemler-sözel eşitlikler sınıflamasına örnek

Yukarıda verilen problem sözel (günlük hayat problemi) olmayan bir problemdir. Cebirsel ifade günlük hayatla ilişkilendirilmeden denklemin sözel olarak ifade edilmesiyle oluşturulduğundan, problem sözel eşitlik sınıflamasına dâhil edilmiştir.

Öğretmen adaylarının sembolik olarak verilen birinci dereceden bir bilinmeyenli denkleme uygun olarak kurdukları problemler incelendiğinde, genel olarak sözel 
matematik problemleri kurabildikleri görülmüştür. Kurulan problemlere kullanılan dil açısından bakıldığında büyük bir kısmının günlük dil ile günlük ve sembolik dil kullanılarak oluşturulduğu tespit edilmiştir. Bazı problemler ise "Bir sayı, bu sayının yarısı ve 6000'den bu sayının 2 katının çıkartılmasıyla elde edilen sayının toplamı 5000'dir. Bu sayı kaçtır?" örneğinde olduğu gibi cebirsel denklemin günlük hayatla ilişkilendirilmeden, denklemin sözel olarak ifade edilmesiyle oluşturulmuştur. Birinci dereceden bir bilinmeyenli denklem konusunda öğretmen adaylarından sadece bir tanesinin çözülemeyen problem kurması da bulgular arasındadır. Öğretmen adaylarının bazılarının denklemde verilen değişken ve sayıların bir kısmını eşitliğin diğer tarafında düşünerek problem kurdukları da belirlenmiştir. Örneğin $x+\frac{x}{2}+(6000-2 x)=5000$ denklemi yerine $x+\frac{x}{2}=2 x-1000$ denklemine uyan problem kuran öğretmen adaylarına da rastlanmıştır.

\subsection{PKT' nin 3.maddesine ilişkin bulgular}

Öğretmen adaylarına yöneltilen 3. soru "Bir tavuk çiftliğindeki tavukların sayısı her ay bir öncekinin 3 katına çıkmaktadır......... ifadesini tamamlayacak şekilde bir problem kurunuz" şeklindedir. 3.soruda yarı yapılandırılmış bir problem durumu verilerek cümleyi tamamlayacak şekilde bir problem kurmaları istenmiştir. Problem teşkil etmeyen kategorisine dâhil edilebilecek ifade görülmemiştir. Öğretmen adaylarının kurmuş oldukları problemler, sözel problemler, sözel olmayan problemler şeklinde sınıflandırılarak problem çeşitlerinin frekans ve yüzdeleri Tablo 3' te verilmiştir.

Tablo 3. Ortaokul matematik öğretmeni adaylarının 3. maddeye ilişkin kurdukları problem çeşitleri

\begin{tabular}{|c|c|c|c|c|c|c|c|c|c|c|c|c|c|c|c|c|c|c|}
\hline \multirow{5}{*}{ Sinıf } & \multicolumn{14}{|c|}{ Sözel Problemler } & \multicolumn{4}{|c|}{$\begin{array}{l}\text { Sözel Olmayan } \\
\text { Problemler }\end{array}$} \\
\hline & \multicolumn{10}{|c|}{ Çözülebilen Problemler } & \multicolumn{4}{|c|}{ Çözülemeyen Problemler } & & & & \\
\hline & \multicolumn{6}{|c|}{ Kullanılan Dil } & \multirow{2}{*}{\multicolumn{2}{|c|}{$\begin{array}{l}\text { Yanlıș } \\
\text { Notasyon }\end{array}$}} & \multirow{2}{*}{\multicolumn{2}{|c|}{$\begin{array}{l}\text { İlgisiz } \\
\text { Veri }\end{array}$}} & \multirow{2}{*}{\multicolumn{2}{|c|}{ Eksik bilgi }} & \multirow{2}{*}{\multicolumn{2}{|c|}{$\begin{array}{l}\text { Yanlış } \\
\text { sayı }\end{array}$}} & \multirow{2}{*}{\multicolumn{2}{|c|}{$\begin{array}{l}\text { Sözel } \\
\text { eşitlikler }\end{array}$}} & \multirow{2}{*}{\multicolumn{2}{|c|}{$\begin{array}{l}\text { Sembolik } \\
\text { eşitlikler }\end{array}$}} \\
\hline & \multicolumn{2}{|c|}{$\begin{array}{c}\text { Sembolik } \\
\text { Dil }\end{array}$} & \multicolumn{2}{|c|}{$\begin{array}{c}\text { Günlük } \\
\text { Dil }\end{array}$} & \multicolumn{2}{|c|}{$\begin{array}{c}\text { Sembolik ve } \\
\text { Günlük Dil }\end{array}$} & & & & & & & & & & & & \\
\hline & f & $\%$ & f & $\%$ & f & $\%$ & f & $\%$ & f & $\%$ & f & $\%$ & f & $\%$ & f & $\%$ & f & $\%$ \\
\hline 2 & - & - & 19 & 19.9 & - & - & - & - & 1 & 1 & 4 & 4.2 & 13 & 13.6 & - & - & - & - \\
\hline 3 & - & - & 15 & 15.6 & 1 & 1 & - & - & 4 & 4.2 & - & - & 10 & 10.4 & - & - & - & - \\
\hline 4 & - & - & 15 & 15.6 & - & - & - & - & 1 & 1 & 1 & 1 & 11 & 11.4 & - & - & 1 & 1 \\
\hline Toplam & - & - & 49 & 51.1 & 1 & 1 & - & - & 6 & 6.3 & 5 & 5.2 & 34 & 35.4 & - & - & 1 & 1 \\
\hline
\end{tabular}

Tablo 3 incelendiğinde öğretmen adaylarının kurdukları problemlerden \%99'u sözel, $\% 1$ 'i sözel olmayan problem olarak sinıflandırılmıştır. Kurulan sözel problemlerden $\% 58.4$ 'ü çözülebilen problemlerdir ve \%6.3'ü ilgisiz veri \%51.1'i günlük dil ve \%1'i günlük ve sembolik dil olarak sınıflandırılmıştır. Öğretmen adaylarının kurdukları sözel problem çeşitlerinden örnekler aşağıda verilmiştir: 
Bir tavuk çifliğindeki tavukların sayısı her ay bir öncekinin 3 katına çıkmaktadır... Gif fl/k tekr

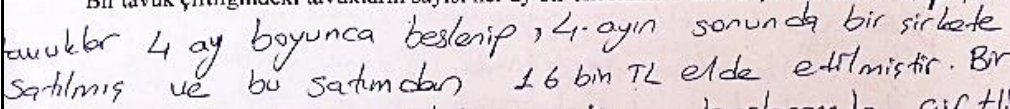

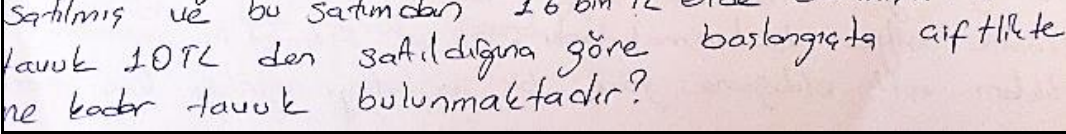

Şekil 9. Sözel-çözülebilen problem-günlük dil sınıflamasına örnek

Şekil 9'da verilen problem çözülebilen bir sözel problemdir. Kullanılan dil açısından ise günlük dil olarak sınıflandırılmıştır. Hikayeleştirildiği için sözel problem, mantıklı bir çözümü olduğundan çözülebilen ve günlük hayatla ilişkilendirildiğinden günlük dil sınıflamasında yer almıştır.

Problemlerin \%40.6'sı çözülemeyen problemlerdir ve bu problemler incelendiğinde öğretmen adaylarının yanlış sayı kullanmasından (\%35.4) ve problemin eksik bilgi ile kurulmasından (\%5.2) kaynaklandığı görülmektedir. Bu sınıflandırmaya uyan problemlere örnekler aşağıda verilmiştir:

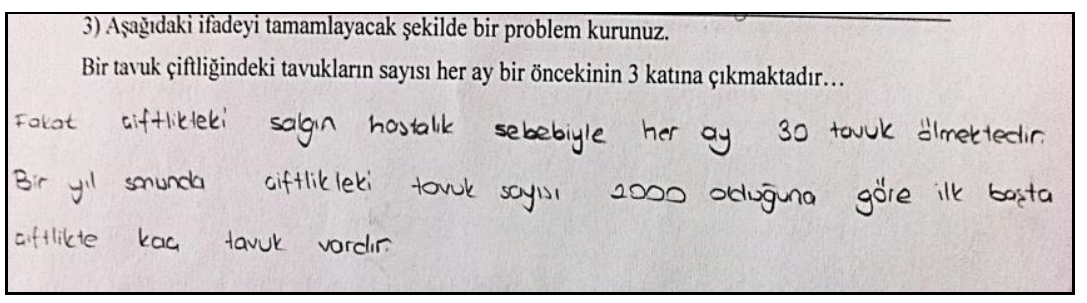

Şekil 10. Sözel-çözülemeyen problem- yanlış sayı sınıflamasına örnek

Şekil 10'daki problem incelendiğinde problem ilk bakışta mantıklı bir sözel matematik problemi olarak görülmektedir. Verilen sayılarla işlem yapıldığında tavuk sayısının tamsayı olarak bulunamadığı görülmektedir hâlbuki tavuk sayısının tamsayı çıkması gerekmektedir. Bunun nedeni ise sayıların yanlış seçimidir. Bu durum problemi kuran öğretmen adayları tarafından göz ardı edilmiştir. Bundan dolayı problem çözülemeyenyanlış sayı sınıflamasına dâhil edilmiştir.

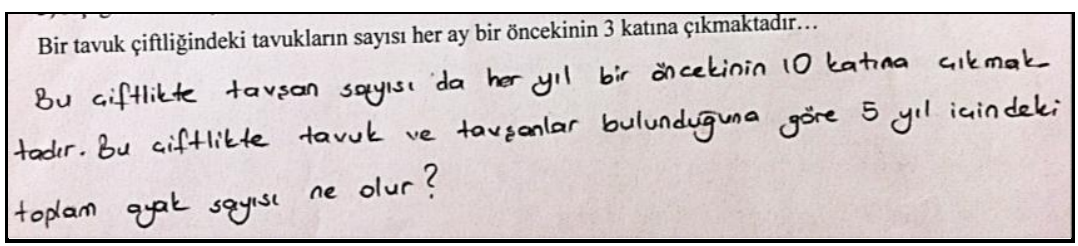

Şekil 11. Sözel- çözülemeyen problem-eksik veri sınıflamasına örnek 


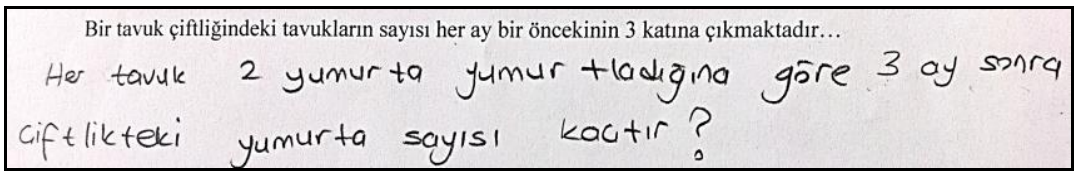

Şekil 12. Sözel- çözülemeyen problem-eksik veri sınıflamasına örnek

Yukarıda verilen problemler çözülemeyen sözel problemlerdir. Şekil 11'deki problemde başlangıçtaki tavuk ve tavşan sayısına ilişkin bilgi bulunmadığından problemin çözümü için veri eksikliği mevcuttur. Bundan dolayı da problem çözülemeyen-eksik veri olarak değerlendirilmişlerdir. Şekil 12'deki problemde de tavuk sayısı bilinmeden üç ay sonraki yumurtaların sayısının hesaplanamayacağı için çözülemeyen-eksik veri şeklinde sınıflandırılmıştır.

Öğretmen adaylarının neredeyse tamamı bu madde için sözel problem kurarken, çözülemeyen problem kuranların oranı da oldukça yüksektir. Kurulan problemler incelendiğinde problemlerde genel olarak günlük dilin kullanıldığı belirlenmiştir. Çözülemeyen problemlerde ise en çok yanlış sayı kullanımı ve ayrıca eksik veri ile problem kurulması durumlarına rastlanmıştır. Problemlerde tavuk sayısının tamsayı çıkmaması gibi yanlış sayı kullanımı, tavuk sayısı verilmeden yumurta sayısının istenmesi ve “...bir süre sonra tavukların saylsı ilk başta alınan tavuk sayısının 81 katından 15 eksiktir. Bu süre zarfinda ölen veya yeni alınan tavuk sayıları kaç olabilir?" şeklinde eksik veri ile problem kurulması gibi durumlar tespit edilmiştir.

\subsection{PKT' nin 4.maddesine ilişkin bulgular}

Öğretmen adaylarından verilen geometrik şekle (cebirsel ifadeye) uygun problem kurmaları istenmiştir. 4. soruda "Kenar uzunluklarl a ve b olan iki kare şekildeki gibi yerleştiriliyor. Bu modelde ifade edilen cebirsel ifadeye uygun bir problem kurunuz." Öğretmen adaylarının kurmuş oldukları problemler, sözel problemler, sözel olmayan problemler ve problem teşkil etmeyenler şeklinde sınıflandırılarak problemlerin frekans ve yüzdeleri Tablo 4' te verilmiştir:

Tablo 4. Ortaokul matematik öğretmeni adaylarının 4. maddeye ilişkin kurdukları problem çeşitleri

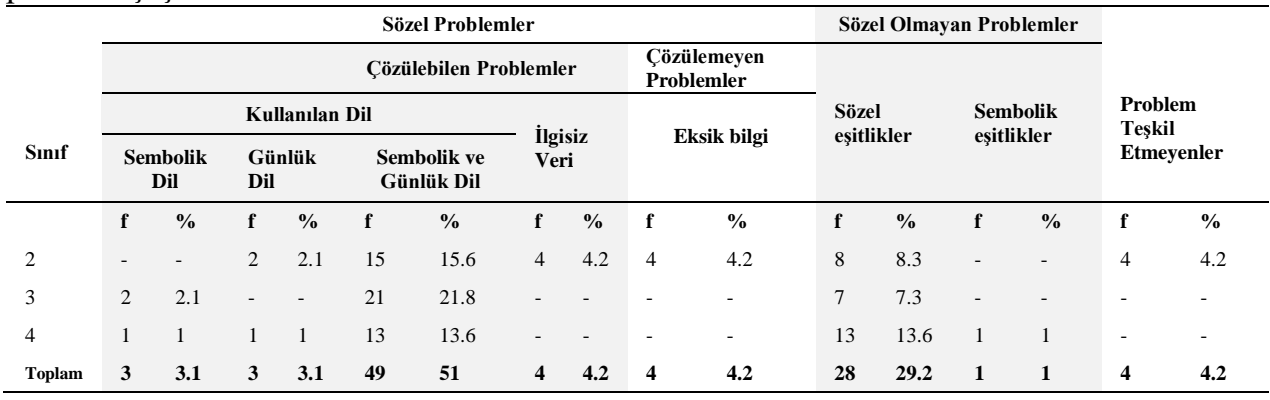


Ortaokul matematik öğretmeni adaylarının verilen geometrik şekle uygun olarak kurdukları problemler incelendiğinde \%65.6's1 sözel matematik problemi, sözel problemlerinin \%61.4'ü çözülebilen problemlerdir. Çözülebilen problemlerin ise \%3.1'i sembolik dil, \%3.1'i günlük dil, \%51'i günlük ve sembolik dil \% 4.2'si ilgisiz veri sınıflamasında yer almıştır. Çözülemeyen problemlerin oranı \%4.2'dir. Bu durum eksik bilgi (\%4.2) kullanılmasından kaynaklanmaktadır. Öğretmen adaylarının kurdukları sözel problem çeşidine örnek aşağıda verilmiştir:

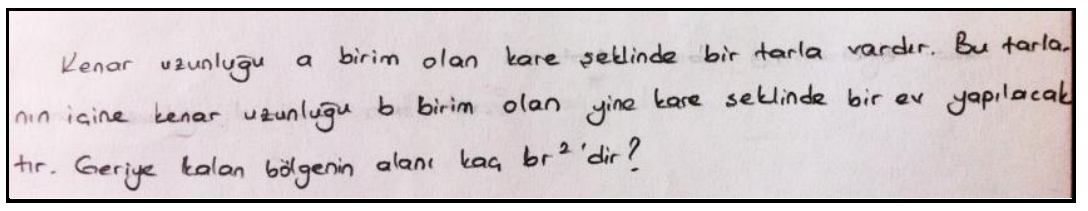

Şekil 13. Sözel-çözülebilen problem-günlük sembolik dil sınıflamasına örnek

Yukarıda verilen problem çözülebilen bir sözel problemdir. Kullanılan dil açısından ise hem günlük dil hem de sembolik dil kullanılarak oluşturulmuş olduğundan günlüksembolik dil sınıflamasına dâhil edilmiştir.

Sözel olmayan problemlerin oranı ise \%30.2'dir. Bu problemlerin \%29.2'si sözel eşitlikler, \%1'i sembolik eşitlikler olarak sınıflandırılmıştır. Bu sınıflamaya ilişkin örnek Şekil 14'te verilmiştir:

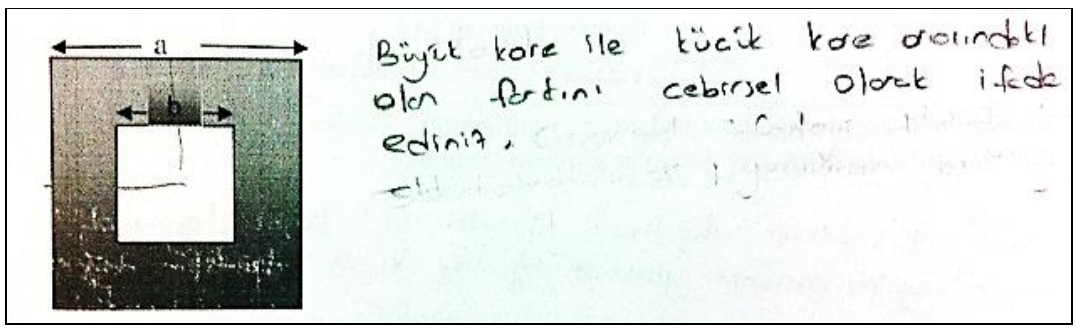

Şekil 14. Sözel olmayan-Sözel eşitlikler sınıflamasına örnek

Şekil 14'teki problem sözel olmayan (hikayeleştirilmeyen) bir problemdir. Cebirsel ifade günlük hayatla ilişkilendirilmeden verilen geometrik şeklin sözel olarak ifade edilmesiyle oluşturulduğundan, problem sözel eşitlik sınıflamasında değerlendirilmiştir.

Öğretmen adaylarının ifadelerinde \%4.2'si ise problem teşkil etmeyenler olarak sınıflandırılmıştır. Bu sınıflamaya örnek Şekil 15 'te verilmiştir: 


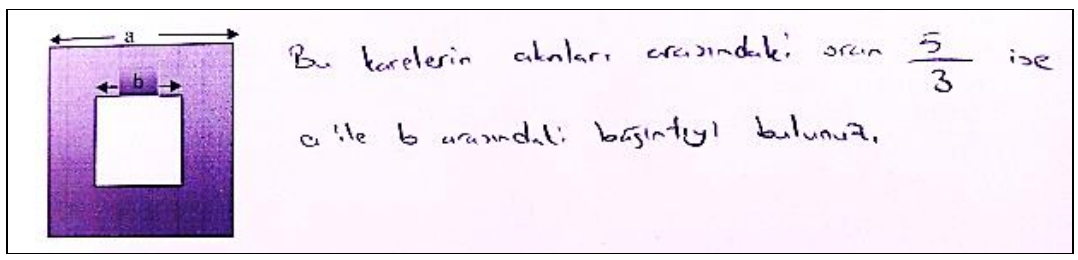

Şekil 15. Problem teşkil etmeyen sınıflamasına örnek

Şekil 15 'te verilen ifade şekilde verilen cebirsel ifadeye uygun bir problem değildir. $\mathrm{Bu}$ yüzden problem teşkil etmeyenler sınıfına dâhil edilmiştir.

Genel olarak öğretmen adaylarının kurdukları problemler incelendiğinde sözel problem kurabildikleri, kurdukları problemlerde ise en çok günlük ve sembolik dil kullandıkları belirlenmiştir. Geometrik şekle sözel eşitlikler sınıflamasında yer alan problemler kuranların oranı da oldukça yüksektir. Öğretmen adaylarının büyük bir çoğunluğunun geometriyi cebirle ilişkilendirebildikleri belirlenmiştir. Öğretmen adayları verilen şekle "bahçe, tarla, arsa, çerçeve, havuz, levha, park, koşu alanı" gibi günlük hayatta kullandığımız gerçek durumlara uygun problem kurabilmişlerdir. Bunun yanında "bir kenarı a birim olan kareden bir kenarı b birim olan kare çıkarllyyor. Yeni oluşan şeklin alanı kaç birim karedir?" şeklindeki problemler de sık kurulan problem türleri arasindadır.

\subsection{PKT' nin 5.maddesine ilişkin bulgular}

PKT'nin 5.maddesinde ise eşit kollu terazi modelindeki cebirsel denkleme uygun olacak bir problem kurmaları istenmiştir. 5. Soru "Verilen eşit kollu terazi modelindeki cebirsel denkleme uygun olacak şekilde bir problem kurunuz." şeklindedir. Öğretmen adaylarının kurmuş oldukları problemler, sözel problemler, sözel olmayan problemler ve problem teşkil etmeyenler şeklinde sinıflandırılmıştır. Problem çeşitlerinin frekans ve yüzdeleri hesaplanmış ve Tablo 5' te verilmiştir:

Tablo 5. Ortaokul matematik öğretmeni adaylarının 5. maddeye ilişkin kurdukları problem çeşitleri

\begin{tabular}{|c|c|c|c|c|c|c|c|c|c|c|c|c|c|c|c|c|c|c|}
\hline \multirow{4}{*}{ Sinıf } & \multicolumn{12}{|c|}{ Sözel Problemler } & \multicolumn{4}{|c|}{$\begin{array}{c}\text { Sözel Olmayan } \\
\text { Problemler }\end{array}$} & \multirow{3}{*}{\multicolumn{2}{|c|}{$\begin{array}{l}\text { Problem } \\
\text { Teşkil } \\
\text { Etmeyenler }\end{array}$}} \\
\hline & \multicolumn{8}{|c|}{ Çözülebilen Problemler } & \multicolumn{4}{|c|}{$\begin{array}{l}\text { Çözülemeyen } \\
\text { Problemler }\end{array}$} & \multirow{2}{*}{\multicolumn{2}{|c|}{$\begin{array}{l}\text { Sözel } \\
\text { eşitlikler }\end{array}$}} & \multirow{2}{*}{\multicolumn{2}{|c|}{$\begin{array}{l}\text { Sembolik } \\
\text { eşitlikler }\end{array}$}} & & \\
\hline & \multicolumn{2}{|c|}{ Günlük Dil } & \multicolumn{2}{|c|}{$\begin{array}{c}\text { Sembolik } \\
\text { ve } \\
\text { Günlük } \\
\text { Dil } \\
\end{array}$} & \multicolumn{2}{|c|}{$\begin{array}{l}\text { Yanlış } \\
\text { Notasyon }\end{array}$} & \multicolumn{2}{|c|}{$\begin{array}{l}\text { İlgisiz } \\
\text { Veri }\end{array}$} & \multicolumn{2}{|c|}{$\begin{array}{c}\text { Eksik } \\
\text { bilgi }\end{array}$} & \multicolumn{2}{|c|}{$\begin{array}{l}\text { Yanlış } \\
\text { sayı }\end{array}$} & & & & & & \\
\hline & $\mathbf{f}$ & $\%$ & $\mathbf{f}$ & $\%$ & $\mathbf{f}$ & $\%$ & $\mathbf{f}$ & $\%$ & $\mathbf{f}$ & $\%$ & $\mathbf{f}$ & $\%$ & $\mathbf{f}$ & $\%$ & $\mathbf{f}$ & $\%$ & $\mathbf{f}$ & $\%$ \\
\hline 2 & 14 & 14.6 & - & - & 1 & 1 & 1 & 1 & 1 & 1 & 1 & 1 & 17 & 17.7 & 2 & 2.1 & - & - \\
\hline 3 & 14 & 14.6 & 1 & 1 & 1 & 1 & - & - & - & - & - & - & 12 & 12.5 & - & - & 1 & 1 \\
\hline 4 & 10 & 10.4 & - & - & 2 & 2.1 & 1 & 1 & - & - & - & - & 16 & 16.7 & - & - & 1 & 1 \\
\hline Toplam & 38 & 39.6 & 1 & 1 & 4 & 4.2 & 2 & 2.1 & 1 & 1 & 1 & 1 & 45 & 46.9 & 2 & 2.1 & 2 & 2.1 \\
\hline
\end{tabular}


Ortaokul matematik öğretmeni adaylarının verilen eşit kollu terazi modeline uygun olarak kurdukları problemler incelendiğinde, \%48.9' unun sözel problem, bu problemlerden \%46.9'unun çözülebilen problemler olduğu görülmüştür. Çözülebilen problemlerin \%39.6's1 günlük dil, \%1'i günlük ve sembolik dil, \%4.2'sinin yanlış notasyon, \%2.1'inin ilgisiz veri sınıflamasında yer aldığı belirlenmiştir. Çözülemeyen problemlerin oranı ise $\% 2$ 'dir. Bu durum, eksik bilgi (\%1) ve yanlış sayı (\%1) ile problem kurmalarından kaynaklanmaktadır. Öğretmen adaylarının kurdukları sözel problem çeşitlerine örnekler aşağıdaki gibidir:

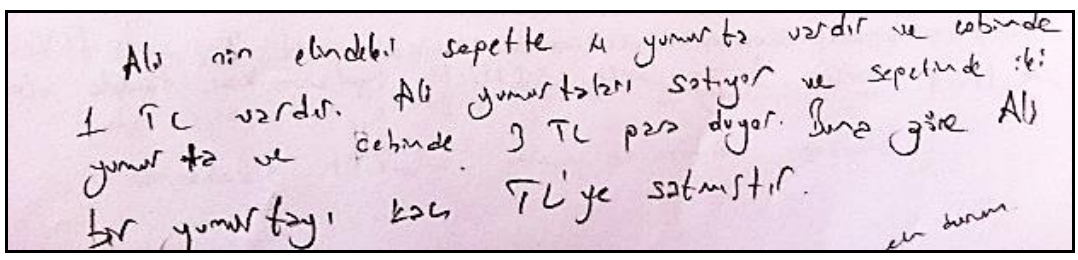

Şekil 16. Sözel-çözülebilen problem-günlük sembolik dil sınıflamasına örnek

Şekil 16'da verilen problem hikayeleştirildiği için sözel bir problemdir. Terazide verilen denklemi karşılayan ve mantıklı sonuçlar veren bir problem olduğundan çözülebilen bir problemdir. Kullanılan dil açısından ise günlük dil olarak sınıflandırılmıştır.

5) Aşağıda verilen eşit kollu terazi modeline uygun olacak şekilde bir problem kurunuz.

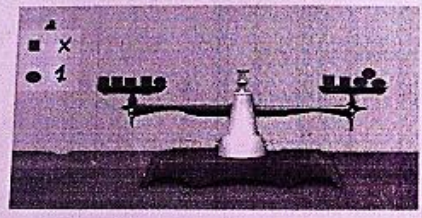

Ales dogumgint Tain pasta yopmok Tstemektedic.

Pastiay, joptikton sonra uzerine ne kodop poro ile kaa mum alacagjn. bilememektedir. Ablas. ona "L TL cebinde kelirso 1 mumn dur ama 2 TL cebinde kalisso 3 mumun viur.". demektedr. Buno göre Alev 4 mum almosigla cebinde ne kodar parasi kalir?

Şekil 17. Sözel- çözülebilen problem- yanlış notasyon sınıflamasına örnek

Şekil 17'de verilen problem çözülebilen sözel bir problemdir fakat kare $\mathrm{x}$, daire 1 olarak modellenmiş olup cebirsel denklem $4 x+1=2 x+3$ şeklinde olması gerekirken, öğretmen adayı problemi $4+x=2+3 x$ cebirsel denklemiyle çözülebilecek şekilde kurmuştur. Bundan dolayı yanlış notasyon şeklinde sınıflandırılmıştır.

Kurulan problemlerinin \%49'unun sözel olmayan problemler oldukları, bunların da \%46.9'unun sözel eşitlikler, \%2.1'inin sembolik eşitlikler sınıflamasında yer aldığ 1 belirlenmiştir. Öğretmen adaylarından sadece \%2'sinin uygun bir problem kuramadığı belirlenmiştir. 


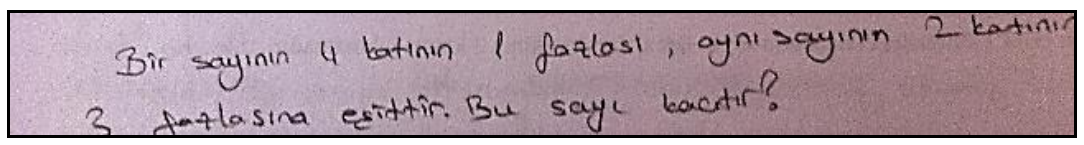

Şekil 18. Sözel olmayan problem-Sözel eşitlikler sınıflamasına örnek

Şekil 18'deki problem hikayeleştirilmediği için sözel olmayan bir problemdir. Cebirsel denklem günlük hayatla ilişkilendirilmeden denklemin sözel olarak ifade edilmesiyle oluşturulduğundan, problem sözel eşitlikler olarak sınıflandırılmıştır.

Genel olarak öğretmen adaylarının günlük dil kullanarak sözel problemler ve sözel eşitlikler kullanarak sözel olmayan problemler kurdukları belirlenmiştir. Öğretmen adaylarından iki tanesi ise $4 x+1=2 x+3$ ise $x=$ ? şeklinde sözel olmayan ve sadece matematiksel sembollerin kullanılmasıyla sembolik eşitlikler sınıflamasında yer alan problemler kurmuşlardır.

\section{Tartışma ve Sonuç}

$\mathrm{Bu}$ araştırmanın amacı, ortaokul matematik öğretmeni adaylarının cebirsel ifade ve denklemlere ilişkin kurdukları problemlerin incelenerek sınıflandırılmasıdır. Araştırmadan elde edilen sonuçlara göre, öğretmen adaylarının genel olarak cebirsel ifade ve denklemlere ilişkin problem kurabildikleri görülmektedir. Korkmaz ve Gür (2006) öğrencilerin yaratıcı ve mantıksal düşünmelerini sağlayacak problem kurma öğretiminin bu konuyla ilgili temel bilgi ve beceriler edinmiş öğretmenler tarafindan yapılacağını belirtmişlerdir. Öğretmen adaylarının problem kurabilmeleri ileride kendi öğrencilerine gerekli olacak problem kurma etkinliklerini planlayabilecek durumda olduklarının bir göstergesi olarak kabul edilebilir. Diğer yandan Işık ve Kar (2012a) öğretmen adaylarının denklemler konusunda problem kurmada zorluklar yaşadıklarını belirtmişlerdir. Ayrıca matematiğin kesirler, denklemler ve üç boyutlu geometri konularında yapılan çalışmalarda öğretmen adaylarının problem kurmakta güçlükler yaşadıkları belirlenmiştir (Crespo \& Sinclair, 2008; Dede ve Yaman, 2005; Işsk, 2011; Işık, Işık ve Kar, 2011; Lavy \& Bershadsky, 2003). Akkan ve arkadaşları (2009) araştırmalarında 6. ve 7.sınıf ögrencilerinin problem durumuna uygun bir denklem oluşturmada, denklem durumuna uygun bir problem kurmaya göre daha yeterli olduğunu belirlemiş̧lerdir. Işık ve Kar'ın (2012b) problem kurmaya ilişkin öğretmen görüşlerinin araştırıldığı çalışmalarında ise matematik öğretmenlerinin 12-15 yaş grubundaki öğrencilerin denklemlerle ilgili problem çözmekte denklemlerle ilgili problem kurmaktan daha başarılı olduklarını düşündüklerini belirlemişlerdir. Çalışmalardan elde edilen sonuçlar bu araştırmaların sonuçlarıyla farklılık göstermektedir. $\mathrm{Bu}$ durum öğretim programlarına problem kurmaya yönelik kazanımların eklenmesiyle, ders kitaplarında ve sinıf ortamında uygulanan etkinliklerde problem kurma çalışmalarına daha fazla yer verilmesinden kaynaklanıyor olabilir. Ayrıca bu durum çalışma grubunda yer alan öğretmen adaylarının 2. 3. ve 4. sınıflardan 
seçilmesi, problem çözme stratejileri ve matematik eğitimi ile ilgili dersler almış olmaları ile de açıklanabilir.

Öğretmen adaylarının kurdukları problemler incelendiğinde, genel olarak sözel problemler kurdukları ve problemlerin çözülebilen problemler olduğu belirlenmiştir. Çözülemeyen problemler ise genellikle yanlış sayı kullanımından kaynaklanmaktadır. Eğer sayılar daha dikkatli seçilseydi problemler çözülebilen problemler haline dönüşebilirdi. $\mathrm{Bu}$ bulgu literatürdeki diğer araştırmalarla paralellik göstermektedir (Crespo, 2003; Kılıç, 2013; Korkmaz ve Gür, 2006). Crespo (2003) araştırmasında öğretmen adaylarının, matematiksel anlamını düşünmeden basit, birkaç işlemle çözülebilen problemler kurduklarını ve ayrıca kurulan problemlerin çözülebilir olup olmadığına dikkat etmediklerini belirtmiştir. Bunun yanında öğretmen adayları verilen cebirsel ifade ve denklemleri günlük hayat ve gerçek durumlarla ilişkilendirebilmektedir.

Öğretmen adaylarının kurdukları sözel matematik problemlerinde genel olarak günlük dil kullandıkları görülmüştür. Ortaokul Matematik Öğretim Programı'nda matematiksel kavramların günlük hayatla ilişkilendirilmesi amaçladığından (MEB, 2013) öğretmen adaylarının problemler kurarken sembolik dilden ziyade günlük dili kullanabilmeleri, cebirsel ifade ve denklemleri günlük hayatla ilişkilendirebilmeleri açısından olumlu bir gelişmedir. Öğretmenlerin, öğrencilerin kavramlar arasındaki karşılıklı geçişleri ve ilişkileri görebilmelerini sağlamak için, ders sürecinde günlük yaşam ile ilişkilendirmeye önem vermesi gereklidir (Baki, 2008). Diğer yandan Akkan ve arkadaşları (2009) ise araştırmalarının sonucunda 6 ve 7. sınıf öğrencilerinin, cebirsel sözel problemlerde kullanılan günlük dilden sembolik dile geçişte zorlandıklarını belirtmişlerdir. Bu nedenle öğretmenlerin derslerinde, öğrencilerinden verilen denklemlerle ilgili hikâyeler yazmaları ve senaryolar üretmelerini istemesi gerektiğini vurgulamışlardır. Alanyazın dikkate alındığında bu araştırmanın sonucunda elde edilen öğretmen adaylarının günlük dili, kurdukları sözel problemlerde kullanabilmeleri ileride öğretmen olduklarında derslerinde cebirsel ifade ve denklemleri günlük hayatla ilişkilendirebileceklerinin bir göstergesi olarak kabul edilebilir.

$\mathrm{Bu}$ araştırmada cebirsel denklemlerin sembolik yapısı değiştirilerek problem kurulması, yanlış sayı ve eksik bilgi kullanılarak çözülemeyen problemler oluşturulması gibi durumlara sıkça rastlanmıştır. Problemler başlangıçta mantıklı görünse de, problemler incelendiğinde tavuk ve insan sayılarının tam çıkmaması, yeterince bilgi verilmeden başka bir şeyin sonucunun bulunmasının istenmesi gibi durumlarla karşılaşılmıştır. Bu sonuç Işık ve Kar'ın (2012a) yaptığı araştırmadan elde ettiği öğretmen adaylarının birinci dereceden bir bilinmeyenli ve iki bilinmeyenli denklemlere ilişkin kurmuş oldukları problemlerde, matematiksel notasyonların (işlemler ve parantezler) yanlış çevrilmesi, bilinmeyenlere gerçekçi olmayan değerlerin verilmesi, denklem yapılarının değiştirilerek problem kurulması gibi hatalar yapıldığının belirlendiği sonuçlar ile örtüşmektedir. $\mathrm{Bu}$ durum öğretmen adaylarının problem kurma esnasında, problemin çözümünü düşünmemelerinden ve problem kurma ile ilgili yeterli deneyime sahip olmamalarından kaynaklanıyor olabilir. Aydoğdu- İskenderoğlu ve Güneş (2016) de araştırmalarında öğretmenlerin derslerde problem kurma etkinliklerinden ziyade, problem çözme 
etkinliklerine yer vermelerinden dolayı öğrencilerde problem kurmaya ilişkin deneyim eksikliği olduğunu ifade etmişlerdir.

Öğretmen adaylarının 4. soruda verilen görsel temsilde (geometrik şekilde) belirtilen cebirsel ifadeye uygun olarak kurdukları problemler incelendiğinde, sözel matematik problemi kurabildikleri, kurdukları problemlerde ise en çok günlük ve sembolik dil kullandıkları belirlenmiştir. Geometrik şekilde belirtilen cebirsel ifadeye uygun olarak sözel eşitlikler sınıflamasında yer alan problem kuranların oranı da oldukça yüksektir. Buradan öğretmen adaylarının büyük bir çoğunluğunun geometriyi cebirle ilişkilendirebildikleri söylenebilir. Öğretmen adayları verilen karesel bölgeleri "bahçe, tarla, arsa, çerçeve, havuz, levha, park, koşu alanı" gibi günlük hayatta kullandığımız gerçek durumlarla ilişkilendirerek problem kurmuşlardır. Bunun yanında "bir kenarı a birim olan kareden bir kenarı b birim olan kare çıkarllyyor. Yeni oluşan şeklin alanı kaç birim karedir?" şeklindeki gibi günlük hayatla fazla ilişkilendirilmeyen problemlere de rastlanmıştır.

Beşinci soruda verilen görsel temsilde (eşit kollu terazi modelinde) ifade edilen cebirsel denkleme yönelik kurulan problemler incelendiğinde, öğretmen adaylarının en sık kurduğu problem türleri sözel eşitlikler şeklindedir. Yani verilen cebirsel denklemin "Bir sayının dört katının bir fazlası aynı sayının iki katının üç fazlasına eşittir" sözel olarak ifade etmesi şeklinde problem kurmaya çalışmışlardır. Bu durum öğretmen adaylarının basit tarzda yani alıştırma tarzında problemler kurmaya meyilli olduklarının göstergesi olarak kabul edilebilir. Bu durumun nedeninin öğretmen adaylarının yapılandırılmamış ve basit problemlerle karşılaştıkları önceki öğrenim yaşantılarından kaynaklandığı söylenebilir (Aydoğdu- İskenderoğlu ve Güneş, 2016).

Genel olarak 4. ve 5. soruda verilen görsel temsillere, diğer sorularda verilen ifadelere uygun olarak kurulan problemlerden daha fazla sözel olmayan türde problem kurulduğu belirlenmiştir. $\mathrm{Bu}$ durum görsel temsilleri sözel olarak ifade etmekte daha çok zorlandıklarını göstermektedir. Görsel temsillerin anlaşılması daha çok performans gerektirdiğinden (Eisenberg \& Dreyfus, 1991) temsilde verilen durumun gerçek yaşam durumlarına aktarılması zordur (Işı1k, Işık ve Kar, 2011). Bu araştırmada da öğretmen adayları görsel temsilleri gerçek yaşam durumlarıyla ilişkilendirmek yerine matematiksel dille ifade etmeyi tercih etmişlerdir.

\section{5. Öneriler}

$\mathrm{Bu}$ araştırmanın sonucunda öğretmen adaylarının cebirsel ifadeler ve denklemler konusunda kurdukları problemler genellikle çözülebilen ve günlük dil kullanılarak kurulan problemler olduğu belirlenmiştir. Öğretmen adaylarının, daha üst düzey düşünmeyi gerektiren problemler kurabilmeleri için matematik eğitimi derslerinde problem kurma becerilerini geliştirmeye yönelik etkinliklere daha fazla yer verilebilir. Öğretmen adaylarının eğitimine yönelik problem kurmayla ilgili seçmeli dersler açılabilir. Yanlış sayı ve eksik bilgi kullanılarak problem kurulması araştırmanın bir sonucu 
olduğundan, öğretmen adayları bu eksiklerini görebilecekleri ve eksikliklerini gidermek için çalışabilecekleri öğrenme ortamlarına dâhil edilebilirler. Öğretmen adaylarının kurmuş oldukları problemlerin zorluk dereceleri (üst düzey düşünmeye yönelik) ve orijinallikleri bu araştırmada incelenmemiştir. Bu durumların ele alındığg çalışmalar da yapılabilir. Farklı örneklemlerde öğretmen adaylarının problem kurma becerilerinin belirleneceği araştırmalar yapılabilir. Ayrıca öğretmenlere yönelik de problem kurma çalışmaları yürütülebilir. Öğretmen adaylarının problem kurarken yaşadıkları düşünsel süreçleri yapılacak nitel araştırmalar ile belirlenebilir. Ayrıca öğretmen adaylarına ortaokul öğrencilerinin kurdukları problemler incelettirilerek hata analizi ve bu hataların düzeltilmesi için çalışmalar yapılması sağlanabilir. 


\section{Examination of Pre-service Elementary Mathematics Teachers' Problems Posed about Algebraic Expressions and Equations}

\section{Extended Abstract}

\section{Purpose and Significance}

The purpose of this study is to examine pre-service elementary mathematics teachers' problems posed about algebraic expressions and equations. Problem posing is an important mathematical activity that has many advantages for students and teachers. Problem-posing situations help students to expand their understanding of mathematics (Stoyanova, 2003), give teachers and students an opportunity to develop their mathematical creativity (Sheffield \& Cruikshank, 2005; Van Harpen \& Sriraman, 2013), is a good diagnostic tool to discover the causes of misconceptions and errors (Ticha \& Hospesova, 2009) and use teaching strategies by pre-service teachers (Toluk-Uçar, 2009). Previous many studies have examined teachers and preservice teachers' problem posing skills in mathematics issue. For examples; fractions (Işık, 2011; Toluk-Uçar, 2009; Ünlü \& Ertekin, 2012), algebraic equations (Işık \& Kar, 2012), absolute value (Güveli, 2015), probability (Silber \& Cai, 2017; Y1ldız \& Baltac1, 2015) and geometry (Lavy \& Bershadsky, 2003; Van Harpen \& Sriraman; 2013). As a result researches indicated that students and pre-service teachers had difficulties about problem posing.

On the other hand algebra has a key role in understanding mathematical concepts (Kieran, 1992; Van Dooren et al., 2002). Therefore, problem posing is effective to establish a conceptual learning on algebraic expressions and equations. In addition teachers need to have knowledge and experience in this area in order to make problem-solving activities for their students. From this point of view, it is important that the teachers are equipped to pose good problems and problem-solving activities for their students (Yenilmez \& Ev-Çimen, 2014). In this regard, it is also essential for pre-service mathematics teachers to determine whether they can pose problems related to algebraic expressions and equations and what kind of problems they can pose. For this context the purpose of this study is to examine preservice elementary mathematics teachers' problems posed about algebraic equations.

\section{Methodology}

Descriptive survey method was used for examining pre-service elementary mathematics teachers' problem-posing about algebraic equations. Data was collected from 96 pre-service elementary mathematics teachers in the spring semester of 2012- 2013 who were enrolled in a teacher education program at a public university. Purposeful sampling method was used to select participants.

Data collection tool consist of 5 open ended items about algebraic expressions and equations. As a result of the literature review items were formed. In order to establish the content validity of the test, expert opinion was sought. 
Pre-service elementary mathematics teachers were asked to pose problems corresponding to the algebraic expressions and equations. After the data collection process, problems were examined and classified. At first problems were classified as story (word) and non-story problems. Then story problems were classified as solvable and non-solvable. Solvable problems also classified as language, wrong notations and irrelevant data. Non- solvable story problems were categorized as wrong number and missing value. Non-story problems were categorized story equations and symbolic equations.

Problems were analyzed by two researchers using the descriptive analysis technique, which is a type of content analysis. They analyzed problems independently from each other and simultaneously. In this process, each researcher formed categories according to the problems posed.

\section{Results}

Pre-service elementary mathematics teachers were asked to pose word problems which are solving by using algebraic equations. Participants' generated problems in free problemposing situations, semi-structured problem situations and visual shapes. Many of preservice teachers posed story and solvable problems. They used daily language in their problems generally. In addition some pre-service teachers posed non- solvable story problems that contain wrong number and missing value.

\section{Discussion and Conclusions}

The findings from the research indicated that pre-service elementary mathematics teachers were generally successful in posing problems related to algebraic expressions and equations. The findings revealed that pre-service elementary mathematics teachers' qualifications about problem posing are enough to plan activities that will be required to develop their students' problem posing skills. On the other hand previous studies showed that teacher candidates have difficulties about problem posing in some mathematics topics such as fractions, equations and three-dimensional geometry (Crespo \& Sinclair, 2008; Dede \& Yaman, 2005, Işık, 2011; Lavy \& Bershadsky, 2003). The results obtained from those studies differ from the results of this research.

When problems types were examined it was determined that some problems were solvable story problems and some were non-solvable problems. Non- solvable problems were posed using wrong number. They did not care whether problems were solvable or not. This result was compatible with the findings of Crespo (2003), Korkmaz and Gür (2006), and Kiliç (2013). Crespo (2003) also indicated pre-service teachers posed simple textbook's questions rather than act creatively.

In general, pre-service teachers posed more non-story problems accordance with the visual representations given in the 4th and 5th questions. Since the understanding of visual representations requires more performance (Eisenberg \& Dreyfus, 1991), it is difficult to transfer the given situation to real life situations (Işı1k, Işık \& Kar, 2011). In this research, too, the teacher preferred not to express mathematical expressions instead of associating visual representations with real life situations. 
More opportunities could be given to improve pre-service mathematics teachers' problem posing skills that require higher levels of thinking in mathematics education courses, and more activities could be done. Elective courses on problem posing could be implemented to pre-service elementary mathematics teachers. Pre-service teachers can be included in the learning environments where they can see and work towards their deficiencies. Research could be done to determine the problem posing skills of pre-service teachers with different samples. In addition, problem posing researches can be conducted on teachers.

\section{Kaynaklar/References}

Akkan, Y., Çakıroğlu, Ü. ve Güven, B. (2009). Equation forming and problem posing abilities of 6th and 7th grade primary school students. Mehmet Akif Ersoy University Journal of Education Faculty, 17, 41- 55.

Aydoğdu-İskenderoğlu T. ve Güneş G. (2016). Pedagojik formasyon eğitimi alan matematik bölümü öğrencilerinin problem kurma becerilerinin incelenmesi. Sakarya University Journal of Education, 6, 26-45.

Baki, A. (2008). Kuramdan uygulamaya matematik eğitimi. (3. bask1). Trabzon: Derya Kitapevi.

Brown, S. I., \& Walter, M. I. (2005). The art of problem posing. New Jersey: Lawrence Erlbaum Associates, Inc.

Brown, C., Carpenter, T., Kouba, V., Lindquist, M., Silver, E., \& Swafford, J. (1988). Secondary school results from the fourth NAEP mathematics assessment: Algebra, geometry, mathematical methods, and attitudes. Mathematics Teacher, 81(5), 337-347.

Büyüköztürk, Ş., Çakmak Kılıç, E., Akgün, Ö., Karadeniz, Ş. ve Demirel, F. (2011). Bilimsel araştırma yöntemleri (10. baskı). Ankara: Pegem Akademi Yayıncılık.

Cai, J., \& Hwang, S. (2002). Generalized and generative thinking in US and Chinese students' mathematical problem solving and problem posing. Journal of Mathematical Behavior, 21, 401-421.

Cortes, A., \& Pfaff, N. (2000). Solving equations and inequations: operational invariants and methods constructed by students. Proceedings of the 24th Conference of the International Group for the Psychology of Mathematics Education (Vol. II, pp. 193200). Hiroshima, Japan: Nishiki Print Co., Ltd.

Crespo, S. (2003). Learning to pose mathematical problems: Exploring changes in preservice teachers' practices. Educational Studies in Mathematics, 52, 243-270.

Crespo, S., \& Sinclair, N. (2008). What makes a problem mathematically interesting? Inviting prospective teachers to pose better problems. Journal Mathematics Teacher Education, 11, 395-415.

Dede, Y. (2004). Öğrencilerin cebirsel sözel problemleri denklem olarak yazarken kullandıkları çözüm stratejilerinin belirlenmesi. Educational Secience and Practice, 4(6), 175-192. 
Dede Y. ve Yaman S. (2005). Matematik öğretmen adaylarının matematiksel problem kurma ve problem çözme becerilerinin belirlenmesi. Ĕgitim Araştırmaları, 5, 41- 56.

Eisenberg, T., \& Dreyfus, T., (1991). On the reluctance to visualize in mathematics. In W. Zimmermann \& S. Cunningham (Eds.), Visualization in teaching and learning mathematics (pp. 25-37). Washington DC: Mathematical Association of America.

English, L. D. (2003). Engaging students in problem posing in an inquiry-oriented mathematics classroom. In F. Lester \& R. Charles (Eds.), Teaching mathematics through problem solving: Prekindergarten-grade 6 (pp.187-198). Reston, Virginia: National Council of Teachers of Mathematics.

Graham, A. T., \& Thomas M. O. J. (2000). Building a versatile understanding of algebraic variables with a graphic calculator. Educational Studies in Mathematics, 41, 265- 282.

Güveli, E. (2015). Prospective elementary mathematics teachers' problem posing skills about absolute value. Turkish Journal of Teacher Education, 4(1), 1-17.

Işık, C. (2011). İlköğretim matematik öğretmeni adaylarının kesirlerde çarpma ve bölmeye yönelik kurdukları problemlerin kavramsal analizi. Hacettepe Üniversitesi Eğitim Fakültesi Dergisi, 41, 231-243.

Işık, C., Işık, A. ve Kar, T. (2011). Matematik öğretmeni adaylarının sözel ve görsel temsillere yönelik kurdukları problemlerin analizi. Pamukkale Üniversitesi Ĕgitim Fakültesi Dergisi, 30, 39-49.

Işık, C., \& Kar, T. (2012a). The analysis of the problems posed by the pre- service teachers about equations. Australian Journal of Teacher Education, 37(9), 93-113.

Işık, C. ve Kar, T. (2012b). Matematik dersinde problem kurmaya yönelik öğretmen görüşleri üzerine nitel bir çalışma. Milli Ĕgitim Dergisi, 194, 199-215.

Kılıç, Ç. (2013). Pre-service primary teachers' free problem-posing performances in the context of fractions: An example from Turkey. The Asia-Pacific Education Researcher, 22, 1-10.

Kieran, C. (1992). The learning and teaching of school algebra. In D. A. Grouws (Ed.), Handbook of research on mathematics teaching and learning (pp. 390-419). New York: Macmillan.

Korkmaz, E. ve Gür, H. (2006). Öğretmen adaylarının problem kurma becerilerinin belirlenmesi. Ballkesir Üniversitesi Fen Bilimleri Enstitüsü Dergisi, 8(1), 64-74.

Lavy, I., \& Bershadsky, I. (2003). Problem posing via "what if not?" strategy in solid geometry a case study. Journal of Mathematical Behavior, 22, 369-387.

Lee, F. (2002, Aral1k). Diagnosing students' algebra errors on the web. Paper presented at Proceedings of the International Conference on Computers in Education (ICCE'02), Auckland, New Zeland: The Printing House.

MEB. (2013). Ortaokul (5-8. sinıflar) matematik öğretim programı. Ankara: MEB Basımevi.

Miles, B. M., \& Huberman, A. M. (1994). Qualitative data analvsis (2nd ed.). London: Sage Publications.

National Council of Teachers of Mathematics [NCTM]. (2000). Principles and standards for school mathematics. Reston, Va: National Council of Teachers of Mathematics. 
Polya, G. (1962). Mathematical discovery: On understanding, teaching, and learning problem solving. New York: John Wiley.

Sheffield, L. J., \& Cruikshank, D. E. (2005). Teaching and learning mathematics prekindergarten through middle school. Hoboken, N.J.: Wiley Jossey Bass Education.

Silber, S., \& Cai, J. (2017). Pre-service teachers' free and structured mathematical problem posing, International Journal of Mathematical Education in Science and Technology, 48(2), 163-184

Silver, E. A. (1994). On mathematical problem posing. For the Learning of Mathematics. 14(1), 19-28.

Stacey, K., \& MacGregor, M. (1997). Ideas about symbolism that students bring to algebra. Mathematics Teacher, 90, 110-113.

Stafylidou, S., \& Vosniadou, S. (2004). The development of students' understanding of the numerical value of fractions. Learning and Instruction, 14, 503-518.

Steinberg, R., Sleeman, D., \& Ktorza D. (1990). Algebra students' knowledge of equivalence of equations. Journal for Research in Mathematics Education, 22(2), 112121.

Stoyanova, E. \& Ellerton, N. F. (1996). A framework for research into students' problem posing in school mathematics. In P. Clarkson (Ed.), Technology in mathematics education (pp.518-525). Melbourne: Mathematics Education Research Group of Australasia.

Stoyanova, E. (2003). Extending students' understanding of mathematics via problem posing. The Australian Mathematics Teacher, 59(2), 32-40.

Şandır, H., Ubuz, B. ve Argün, Z. (2002, Eylül). Ortaöğretim 9. sinıf öğrencilerinin mutlak değer kavramındaki ögrenme hatalart ve kavram yanılgıları. V. Ulusal Fen Bilimleri ve Matematik Eğitimi Kongresi'nde sunulan bildiri. Orta Doğu Teknik Üniversitesi, Ankara.

Şengül, S. \& Katranc1, Y. (2012). Problem solving and problem posing skills of prospective mathematics teachers about the 'sets' subject. Procedia - Social and Behavioral Sciences, 69, $1650-1655$.

Şengül, S. \& Katranc1, Y. (2015). Free problem posing cases of prospective mathematics teachers: Difficulties and solutions. Procedia - Social and Behavioral Sciences, 174, $1983-1990$.

Ticha, M., \& Hošpesová, A. (2009, Ocak). Problem posing and development of pedagogical content knowledge in pre-service teacher training. Paper presented at Congress of European Research in Mathematics Education (CERME 6), Lyon, France.

Toluk-Uçar, Z. (2009). Developing pre-service teachers understanding of fractions through problem posing. Teaching and Teacher Education, 25(1), 166-175.

Tsamir P., \& Bazzini, L. (2004). Consistencies and inconsistencies in students' solutions to algebraic 'single-value'inequalities. International Journal of Mathematical Education in Science and Technology, 35(6), 793-812. 
Ünlü, M. \& Ertekin, E. (2012). Why do pre-service teachers pose multiplication problems instead of division problems in fractions? Procedia - Social and Behavioral Sciences, 46, $490-494$.

Van de Walle, J., Karp, K., \& Bay-Williams, J. (2012). Illkokul ve ortaokul matematiği: gelişimsel yaklaşımla ögretim. (S. Durmuş, Çev. Ed.). Ankara: Nobel Yayıncılık.

Van Harpen, X. Y., \& Sriraman, B. (2013). Creativity and mathematical problem posing: an analysis of high school students' mathematical problem posing in China and the USA. Educational Studies in Mathematics, 82, 201-221.

Van Dooren, W., Verschaffel, L., \& Onghena, P. (2002). The impact of preservice teachers' content knowledge on their evaluation of students' strategies for solving arithmetic and algebra word problems. Journal for Research in Mathematics Education, 33(5), 319351.

Vlassis, J. (2004). Making sense of the minus sign or becoming flexible in 'negativity'. Learning and Instruction, 14, 469-484.

Yenilmez, K. ve Ev-Çimen (2014). Matematik öğretmeni adaylarının "örnek, alıştırma, problem” oluşturma çalışmalarının incelenmesi. Eğitim ve Öğretim Araştırmaları Dergisi, 3(3), 76-84.

Yıldız, A. ve Baltacı, V. (2015). İlköğretim matematik öğretmen adaylarının problem kurma etkinlikleri ile olasılığa yönelik bilgilerinin incelenmesi. Ahi Evran Üniversitesi Kırşehir Eğitim Fakültesi Dergisi (KEFAD), 16(1), 201-213.

\section{Kaynak Gösterme}

Ünlü, M. ve Sarpkaya-Aktaş, G. (2017). Ortaokul matematik öğretmeni adaylarının cebirsel ifade ve denklemlere yönelik kurdukları problemlerin incelenmesi. Türk Bilgisayar ve Matematik Eğitimi Dergisi, 8(1), 161-187.

\section{Citation Information}

Ünlü, M. \& Sarpkaya-Aktaş, G. (2017). Examination of pre-service elementary mathematics teachers' problems posed about algebraic expressions and equations. Turkish Journal of Computer and Mathematics Education, 8(1), $161-187$. 